\title{
A geological study on Upper Bhuban Formation in parts of Surma Basin, Aizawl, Mizoram
}

\author{
Bubul Bharali ${ }^{1 *}$, Pradip Borgohain ${ }^{2}$, Devojit Bezbaruah ${ }^{1}$, V. Vanthangliana ${ }^{3}$, \\ Parakh Protim Phukan ${ }^{1}$, Raghupratim Rakshit ${ }^{1}$ \\ ${ }^{\text {I}}$ Department of Applied Geology, Dibrugarh University, Dibrugarh 786004, Assam, India \\ ${ }^{2}$ Department of Petroleum Technology, Dibrugarh University, Dibrugarh 786004, Assam, India \\ ${ }^{3}$ Department of Geology, Pachhunga University College, Aizawl 796oor, Mizoram, India
}

\begin{abstract}
Tertiary sediments are thickly deposited in most part of the northeast India attaining a maximum thickness of $\pm 7 \mathrm{~km}$ sedimentary succession. Surma basin located in the eastern proximity of India is also characterized by a thick sedimentary column which can be considered as the northeastern extension of Greater Bengal basin. This basin was initiated due to the mutual collision between Indian and Burmese Plate. Due to this collision, the bed rocks have undergone folding which are oriented N-S trending hill ranges. The basin was also cut by a number of parallel to sub-parallel transverse faults and thrusts. The litho association is consisting of sandstone, siltstone, shale and their various proportions. The present study focused on the provenance of the sediments, tectonic settings of the basin and various paleoclimatic conditions prevailing during the time of deposition by using petrography, granulometric and heavy mineral analysis of representative rock samples which were collected from various parts of Aizawl district of Mizoram belonging to the Upper Bhuban Formation. Based on the various proxies it was confirmed that the sediments were primarily derived from surrounding orogens and deposited in a shallow marine basin under the influence of fluvial-deltaic conditions which were basically sourced from felsic provenance. The sediments were moderately weathered under semi-humid to humid climatic condition before they deposited into Surma basin. Sandstones samples are litharenite and wacke type which were deposited in an active continental margin to recycled orogen settings.
\end{abstract}

Key words: Mizoram; Sandstone; Surma Basin; Upper Bhuban Formation.
Received 18 August 2017 Accepted 04 September 2017

*For correspondence $\mathbb{\square}$ bubulearth@gmail.com

\section{Introduction}

Tertiary sedimentary rocks are thickly deposited in the northeastern part of India that constitutes the Surma basin, which can be considered as northeastern extension of the Greater Bengal
Basin. It was formed due to mutual collision between Indian and Burmese plate. The sedimentation pattern of Surma basin was mainly controlled by the eastern subduction, ${ }^{1-3}$ and also the suture closing event. ${ }^{4}$ It is bounded by number of orogens viz. Himalayan ranges in the north, shillong plateau in the northwestern corner, 
Naga hills in the northeastern corner and IndoBurmese ranges (IBR) along the eastern side. Surma basin was started its evolution during late Oligocene in a shallow marine condition and it formed one of the largest delta complexes of the world which covered more than 200,000 sq. km. ${ }^{5}$ The litho association comprises basically alternate sequences of transgressiveregressive facies dominantly consisting of sandstone, shale and siltstone ${ }^{6}$ attaining a maximum thickness of about $\pm 7 \mathrm{~km}$ in Mizoram. ${ }^{1}$ The topography formed a N-S trending hill ranges which emerges due to the subduction event.

Sediment often preserves their nature of sources, weathering and paleo-climatic conditions, tectonic configuration including various hydrodynamic conditions of the sediments, depositional environmental etc. A combine study of various proxies viz. petrography, granulometric and heavy mineral analysis are helpful to constrain the provenance, ${ }^{7,8}$ tectonic settings,, 10 paleo-climatic conditions including weathering parameters, ${ }^{11-13}$ and also the depositional environment. ${ }^{14-19}$

The present study was carried out along $\mathrm{Ai}$ zawl-Sairang and Aizawl-Tuirial road section of Aizawl district where the Upper Bhuban Formation is well exposed. The aim of the present work is to understand the provenance, tectonic settings, depositional environment and paleoclimatic conditions of Upper Bhuban Formation of Surma Group by using petrography, grain size and heavy mineral analysis. The study area falls in an important geotectonic setting between Indo-Burmese plate collisional zone. Surma ba$\sin$ is identified as a potential petroliferous basin of India and presently renowned oil companies are engaged in hydrocarbon exploration.

\section{Geological Settings of Surma Basin}

Sedimentary sequences of Surma Basin consisted of a shallow marine to deltaic complexes with repetitive transgressive-regressive facies. During late Oligocene, Surma basin was started its evolution with the deposition of Barail sediments which can be considered as a base for the deposition of Miocene Surma Group. The Barail sediments were thrusted over the Surma Group of rocks along Indo-Burmese arc. ${ }^{3}$ Moreover, along the western margin the molasse facies known as Tipam Group were deposited. The Surma sediments were deposited in a shallow basin and in subsequent geologic time they were folded and faulted by the end of Oligocene due to collision between Indian and Burmese plate which still shaping the topographic expression of the basin. This stress force is responsible for the deformation of the entire bed rocks through long strike slip faults. ${ }^{2}$ Rocks are subjected to N$S$ trending folded mountain belt that can also be considered with the evolution of Jura mountain.? The basin forms a convex arc shape towards west which is generally wider in the central part with compare to the southern part and complexity is gradually increasing towards the marginal orogen. ${ }^{3}$ Surma basin was also intersected by a number of parallel to sub-parallel transverse faults and thrusts which are trending NE-SW, ENE-WSW and NW-SE direction. Among these the most prominent transverse fault outcropped between Aizawl and Lunglei district, Mizoram trending along NW-SE direction known as 'Mat River Fault' which has dextral slip motion.,20 The geological map of Mizoram is showing in the Figure $1 .{ }^{21}$

Limited research has been carried out in selective parts of Surma basin. ${ }^{1-3,20}$ Tiwari et al. ${ }^{22}$ initially reported the Skolithos and Cruziana ichnofacies from Bhuban Formation which suggested that the sandy shifting substrate to poorly sorted soft substrate associated with high energy conditions in foreshore zone to low energy condition in the shoreface offshore zone. Again, based on the study of ichnofossils, Rajkonwar et al. ${ }^{23}$ reported that the Upper Bhuban Formation was deposited under fluctuating energy conditions within foreshore to shoreface zones of shallow marine environment. Magnetostratigraphic study carried by Tiwari et al. ${ }^{24}$ and Malsawma et al. ${ }^{25}$ suggested that the sedimentation rate was considerably higher for Upper Bhuban Formation with compare to Middle Bhuban Formation and both the lithounits were deposited under fluctuating environmental conditions from shallow marine to pro-delta facies. 


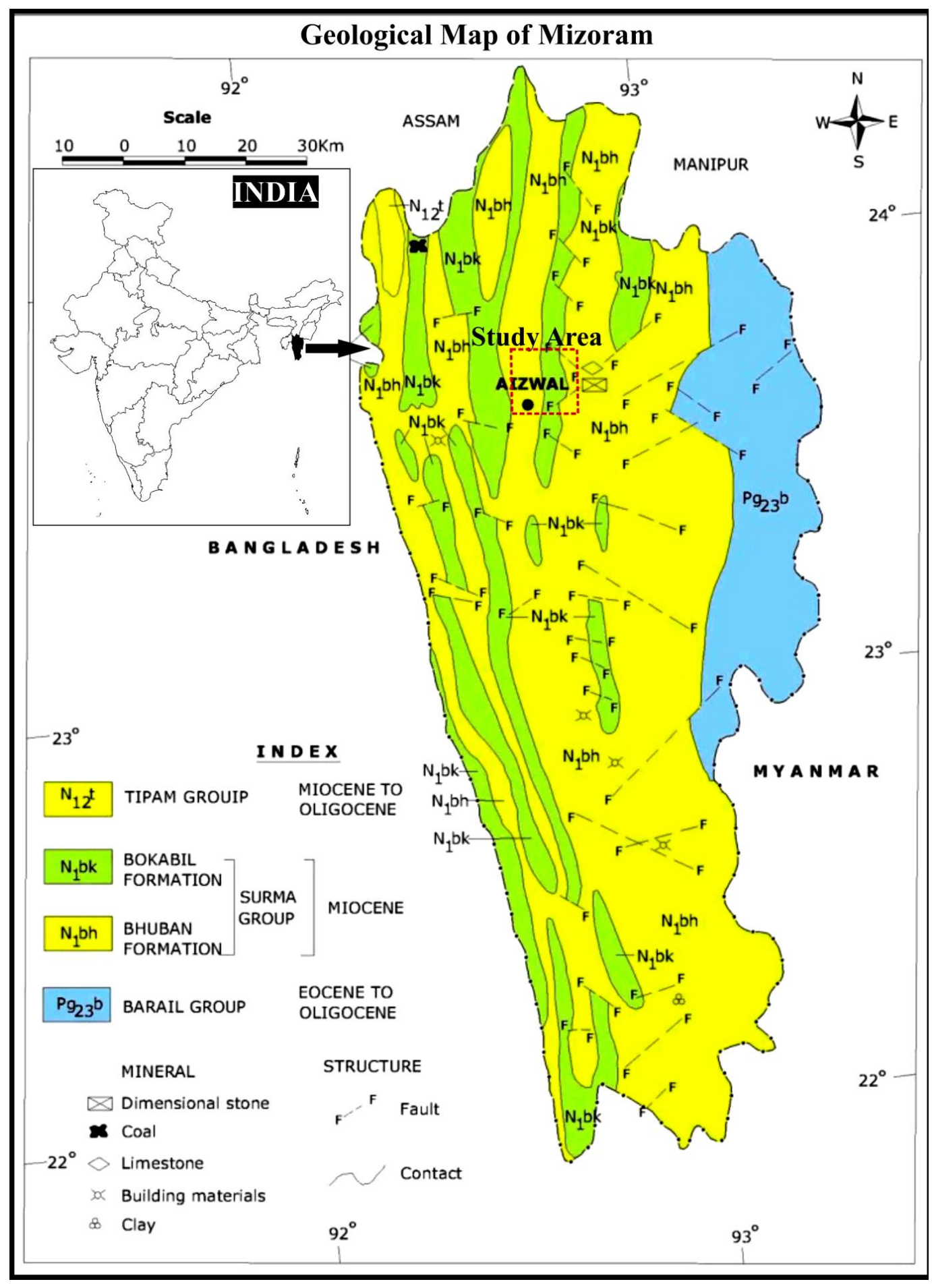

Figure 1 | Geological map of Mizoram showing the study area. ${ }^{21}$ 
Table 1 | Litho-stratigraphic succession of Mizoram. ${ }^{1}$

\begin{tabular}{|c|c|c|c|c|}
\hline Age & Group & Formation & Unit & Generalized Lithology \\
\hline Recent & Alluvium & & & Silt, clay and gravel \\
\hline & --- & ----- & --Unconformity- & 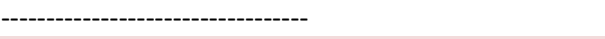 \\
\hline $\begin{array}{l}\text { Early Pliocene } \\
\text { to } \\
\text { Late Miocene }\end{array}$ & $\begin{array}{c}\text { Tipam } \\
\text { (+900 m) }\end{array}$ & & & Friable sandstone with occasional clay bands \\
\hline & ---------------.- & -------Conf & ble and transitio & contact------------------------- \\
\hline \multirow{7}{*}{$\begin{array}{c}\text { Miocene } \\
\text { to } \\
\text { Upper Oligocene }\end{array}$} & \multirow{7}{*}{ 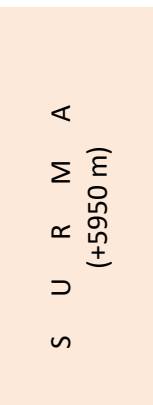 } & $\begin{array}{l}\text { Bokabil } \\
(+950 \mathrm{~m})\end{array}$ & & Shale, siltstone and sandstone \\
\hline & & \multirow{5}{*}{$\begin{array}{ll}z & \\
\varangle & \Xi \\
\infty & \varnothing \\
\supset & \text { 으 }\end{array}$} & \multicolumn{2}{|c|}{-----------Conformable and transitional contact------------- } \\
\hline & & & $\begin{array}{l}\text { Upper Bhuban } \\
\text { (1100 m) }\end{array}$ & $\begin{array}{l}\text { Arenaceous predominating with sandstone, shale } \\
\text { and siltstone }\end{array}$ \\
\hline & & & \multicolumn{2}{|c|}{-------Conformable and transitional contact-- } \\
\hline & & & $\begin{array}{l}\text { Upper Bhuban } \\
\text { (3000 m) }\end{array}$ & $\begin{array}{l}\text { Argillaceous predominating with shale, siltstone- } \\
\text { shale alternations and sandstone }\end{array}$ \\
\hline & & & \multicolumn{2}{|c|}{-------Conformable and transitional contact-- } \\
\hline & & $\bar{\infty}$ & $\begin{array}{l}\text { Lower Bhuban } \\
\qquad(900 \mathrm{~m})\end{array}$ & $\begin{array}{l}\text { Arenaceous predominating with sandstone and } \\
\text { silty-shale }\end{array}$ \\
\hline \multicolumn{5}{|c|}{--------------------------------Unconformity obliterated by faults----------------------------- } \\
\hline Oligocene & $\begin{array}{c}\text { Barail } \\
(+3000 \mathrm{~m})\end{array}$ & & & Shale, siltstone and sandstone \\
\hline
\end{tabular}

The lithostratigraphic succession of Surma Basin is divided into the Oligocene Barail Group, the Miocene Surma Group and the Tipam Groups in the ascending order as given in the Table 1. Surma Group has been divided into Bhuban and Bokabil Formation which is the best developed lithounit of Surma Basin attaining a thickness of more than 5000 meter. Again the Bhuban Formation is subdivided into Lower, Middle and Upper Bhuban units. Upper Bhuban Formation comprises of an arenaceous succession predominating with sandstone, shale and siltstone.

\section{Field description of the study area}

Upper Bhuban Formation is well exposed along the road section from Aizawl to Sairang. This section is dominantly composed of massive sandstone with minor shale and siltstone. A large number of sedimentary structures and trace fossils with few occurrence of mega fossils have been encountered. The lithology is changing from Sairang to Aizawl. Arenaceous lithounits are dominant while in some places argillaceous units are encountered. Sedimentary structures like lenticular and flaser beddings are commonly associated with the bed rocks. Interbedded sandstone and shale occurs with the association of some kinds of diagenetic nodules. Bioturbation with vertical burrows are also associated with the rocks. Similarly, along the Aizawl -Tuirial road section the Upper Bhuban Formation is well exposed. Massive sandstone beds are found to be associated with shale and siltstones which are moderately weathered in some places. Shallow water sedimentary structures like ripple marks, vertical burrows, flaser beddings are also observed. A number of minor faults have been cut the road section. Beds are dips at $45^{\circ}$ to $75^{\circ}$. The vertical lithocolumn of the field sections are given in the Figure 2, and representative field photographs are showing in the Figure 3.

\section{Methodology}

Sandstone samples were collected from various sites. Attitude of bed rocks, encountered sedimentary structures, and lithofacies variation 
Figure 2 | Lithocolumn of the studied sections.

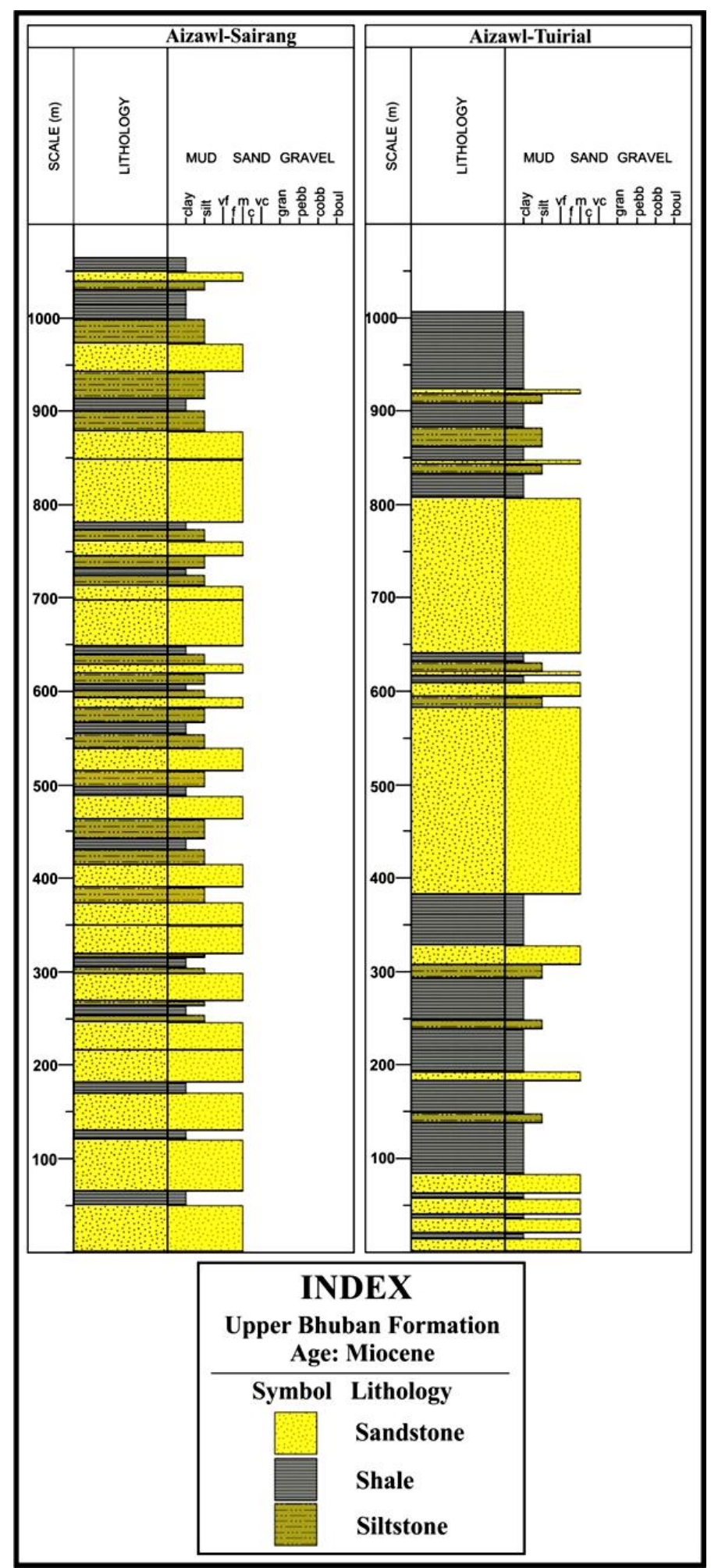


Figure 3 | Field photographs of the study area. A: Massive sandstone bed with alternate bands of sandstone and siltstone along Aizawl-Sairang road section, B: Siltstone intercalations between sandstone beds, C: Chevron folding observed along Aizawl-Sairang road section, D: Bioturbation developed within sandstone, E: jointed steep sandstone beds along AizawlTuirial road section and $\mathrm{F}$ : bivalves associated with weathered sandstone beds along Aizawl-Sairang road section.
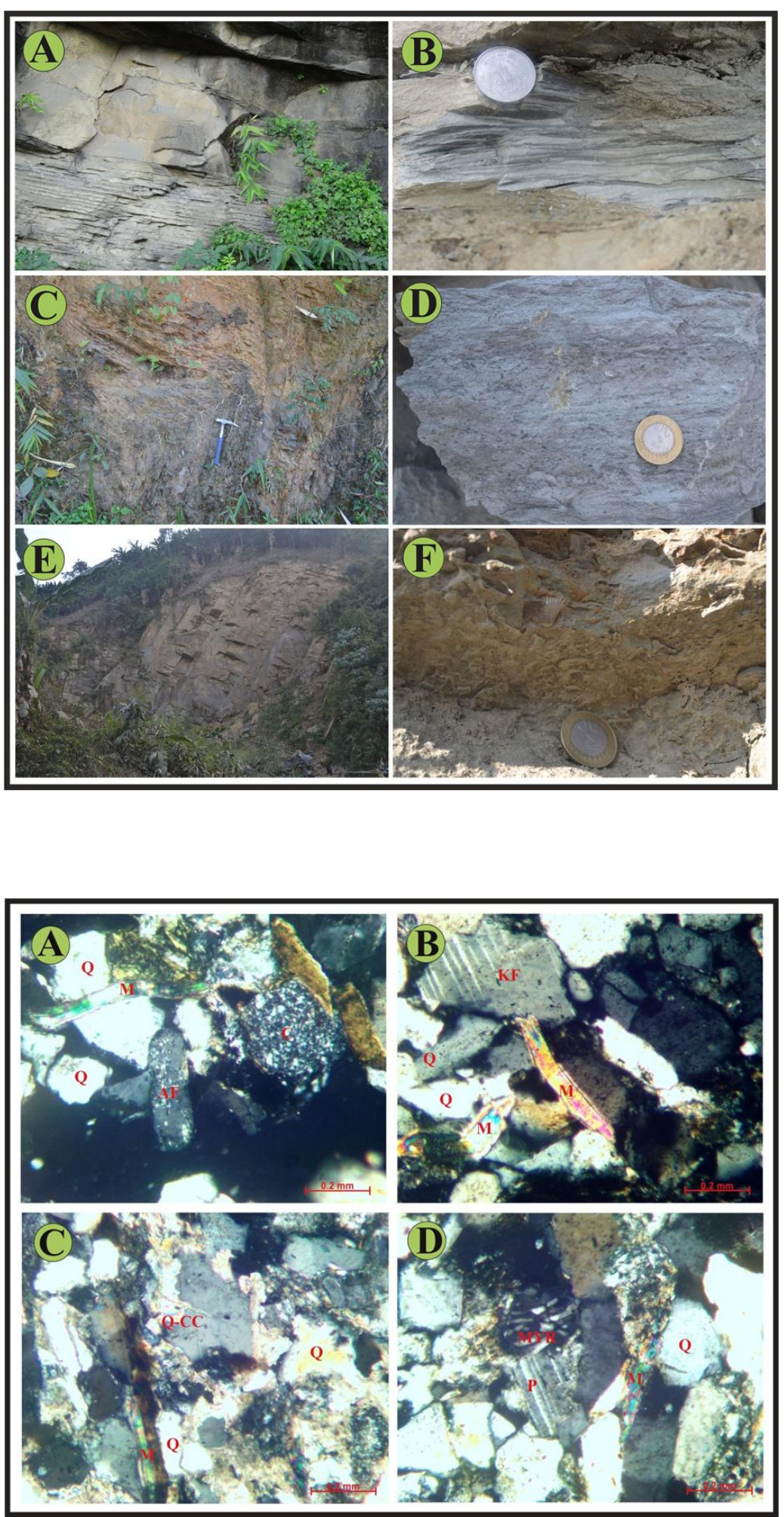

Figure 4 | Photomicrographs of Upper Bhuban sandstone (where, Q: Quartz, P: Plagioclase, KF: K-Feldspar, M: Mica, AF: Altered Feldspar, C: Chert, RF: Rock Fragment, MYR: myrmekite \& Q-CC: quartz overgrowth with carbonate cement). 
were recorded. Granulometric analysis was performed, and vertical lithocolumn of the studied sections were prepared.

Thin sections of the sandstone samples were analyzed using Leica DM 4500 HD petrological microscope, and PETROG automatic motorized Stepping Stage was used to count various framework grains by using Gazzi-Dickinson Point counting method. ${ }^{26-28}$ The samples were crushed with an agate mortar for analyzing grain size and separation of heavy minerals. Grain size was analyzed by using Ro Top sieve shaker with standard sieve sets. Heavy minerals are separated by putting the crushed samples into heavy liquid (bromoform) using a separating tool. Petrographic data, grain size parameters and heavy mineral data are listed in the Table $2, \mathrm{Ta}$ ble 3 , Table 4 , and Table 5 respectively.

\section{Petrography and diagenesis of sandstones}

Upper Bhuban sandstones are medium to fine grained, massive and moderately to well sorted. Quartz grains were dominant and are the most common detrital constituents constituting an average of $43.28 \%$ of the total framework grains. Lithic fragments (avg. 7.50\%), feldspars (avg. 5.71\%) and micas (avg. 9.82\%) were also found. Quartzs are sub-angular to sub-rounded in shape which are generally mono-crystalline in nature, but poly-crystalline varieties are also found. The mono-crystalline varieties are generally non-undulatory but some of them are also showing undulatory extinction. Poly-crystalline quartzs are observed in both varieties i.e. 2-3 and $>3$ grains per quartz. Quartzs are characterized by straight contacts but the point and sutured contact boundaries are also observed. Polycrystalline quartzs are sourced mainly from metamorphic sources, but also from plutonic rocks. Among the poly-crystalline varieties the $>3$ crystal units per grain (avg. $4.23 \%$ ) is dominant over the 2-3 crystal units per grain (avg. $2.58 \%$ ). Overgrowth and authigenic varieties of quartz are also observed. In few sections the floating nature of framework grains within the matrix or cement is observed.

Feldspars constitute $2.33-8.00 \%$ of total framework grain population. Plagioclases are more abundant than K-feldspar. In some sections, perthite (intergrowth between plagioclase and $\mathrm{K}$-feldspars) and altered feldspars (to sericite) grains are observed.

Both varieties of phyllosilicates, i.e. allogenic and authigenic, are commonly observed constituting $9.82 \%$. Muscovites are more dominant than biotite due to their higher resistance to chemical alteration. Authigenic varieties of micas mainly originated from argillaceous cement and matrix which indicates late stage of diagenesis. Few grains occurred as bending and occupy their position in between the framework grains. Chlorites are also rarely observed. Among the clay minerals, kaolinite occurred in the form of fine mosaic like masses of crystals often replacing feldspar in the interstices of detrital grains.

Matrix is the common binding material constituting $12.97 \%$, and is basically derived during diagenesis by alteration of framework grains or due to precipitation of clay minerals. Cementing materials like silica, clay minerals and carbonates are also observed in few thin sections. Petrographic data and photomicrographs are given in the Table 2 and Figure 4 respectively.

\section{Results}

\section{Granulometric analysis and depositional en- vironment}

Based on the granulometric data the cumulative weight\% vs grain size curves are prepared that shows S-type slope as represented in the Fig. 5A. The various grain size parameters are given in the Table 3 and Table 4 . The curves are showing at both coarse and fine ends are almost steep, but in the middle portion of the curves are almost gentle. This pattern represented that some models showed better sorting at the coarser end while some are at the fine end. The middle part is not showing any good sorting. Therefore, the sediments of the Upper Bhuban Formation are moderately sorted.

Graphic standard deviation $\sigma_{1}$ proposed by 

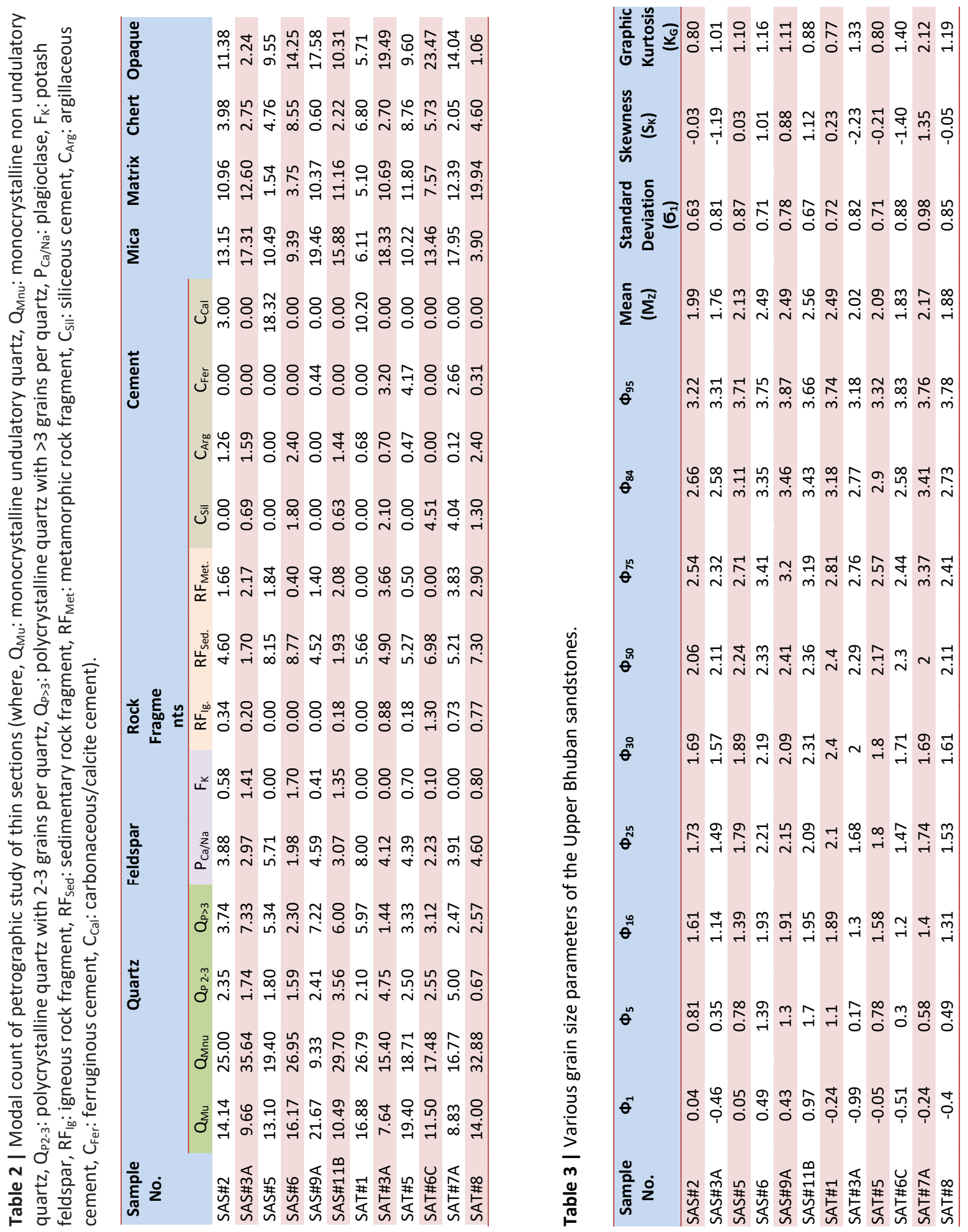

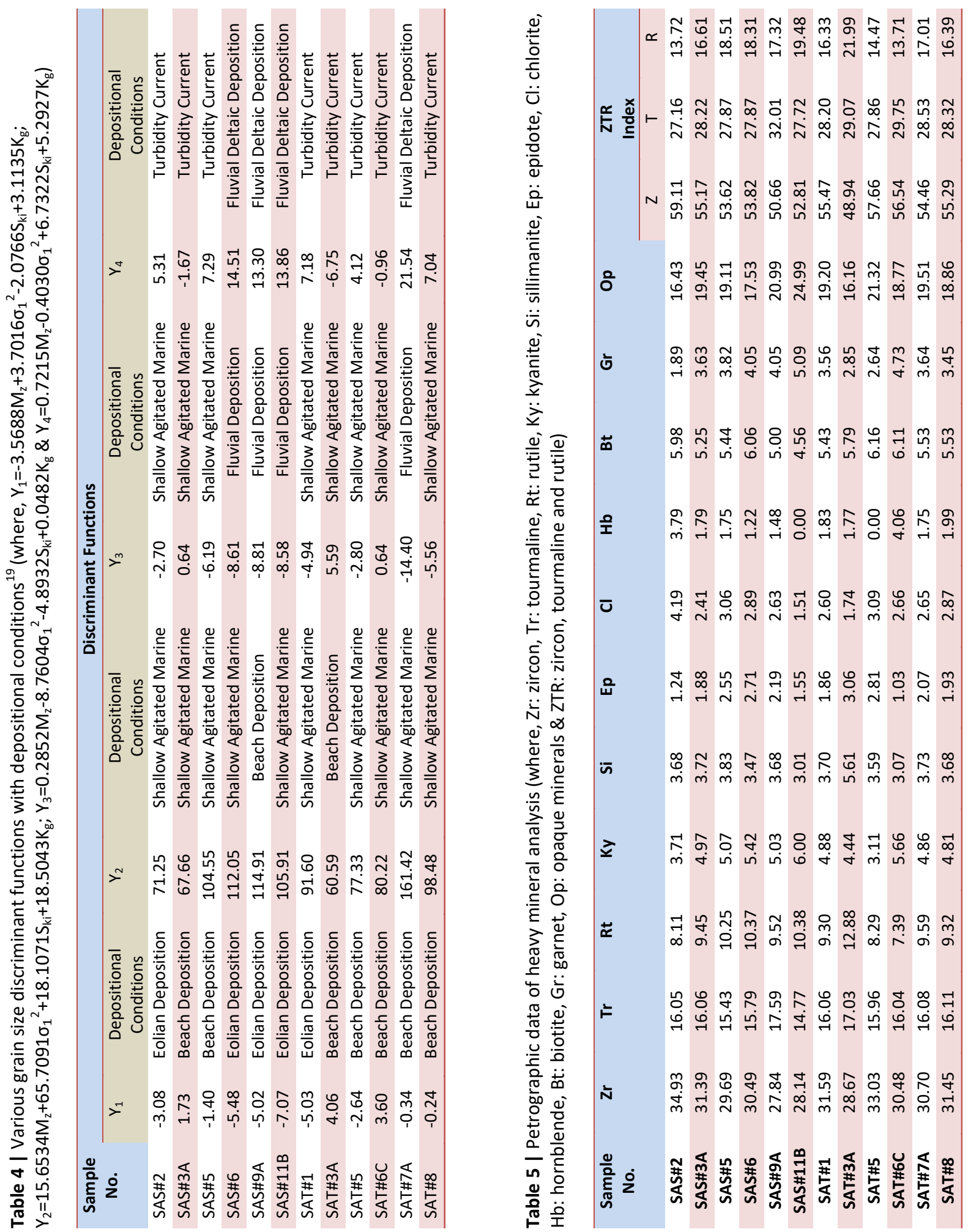
Folk and Ward $\mathrm{d}^{13}$ was used to measure the sorting or uniformity of the grains. Around $66.66 \%$ of the samples are moderately sorted $\left(\sigma_{1}: 0.72-0.98\right)$ and $33.33 \%$ : moderately well sorted $\left(\sigma_{1}: 0.63-0.71\right)$. Again skewness $\left(S_{k i}\right)$ provides the degree of asymmetry in the frequency curves in terms of domination of fine or coarse-grained fractions which was proposed by Folk and Ward..$^{13}$ Upper Bhuban sandstones are showing around $33.33 \%$ of the samples to be strongly fine skewed $\left(S_{k i}\right.$ $=0.88$ to 1.35$), 25 \%$ are strongly coarse skewed $\left(S_{\mathrm{ki}}=-1.19\right.$ to -2.23$)$ and $25 \%$ are near symmetrical $\left(S_{\mathrm{ki}}=0.03\right.$ to -0.05$)$. Maximum samples are strongly fine skewed ranging from 0.88 to 1.35 , denoting that the velocity of the depositing agent operated at a lower velocity. While some of the samples are coarse skewed indicating an increase in velocity of the depositing agent. Cadiga ${ }^{14}$ proposed Kurtosis $\left(\mathrm{K}_{\mathrm{G}}\right)$ that measures the peakedness of the frequency curve. $33.33 \%$ was very leptokurtic, $33.33 \%$ platykurtic, $25 \%$ mesokurtic and $8.3 \%$ very platykurtic in nature. Therefore, both the central position and the tails are somewhat moderately sorted.

The statistical grain size parameters are plotted in the binary plot following previous works. ${ }^{15}$ ${ }^{-19}$ According to the binary plot of Graphic Mean $\left(\mathrm{M}_{\mathrm{z}}\right)$ vs Standard Deviation $\left(\sigma_{1}\right)$ Friedman ${ }^{15}$ the samples are clustered in the field of beach condition (Fig. 5B) with some influence of fluvial characters indicating a shallow marine depositional condition. Similarly, the binary plot by Goldberry ${ }^{16}$ (Fig. 5C) indicated that the Upper Bhuban sandstones were deposited by wave processes. The bivariate plot of Skewness $\left(S_{\mathrm{ki}}\right)$ vs Kurtosis $\left(\mathrm{K}_{\mathrm{G}}\right)$ plot proposed by Friedman ${ }^{17}$ showed that Upper Bhuban sandstones are showing the dominance of beach condition prevailing at the time of deposition affected by river processes (Fig. 5D). Moreover, a binary plot of Skewness $\left(\mathrm{S}_{\mathrm{ki}}\right)$ vs Kurtosis $\left(\mathrm{K}_{\mathrm{G}}\right)$ by Thompson ${ }^{18}$ showed high energy condition prevailing at the time of deposition which indicates the sediments were deposited under marine condition (Fig. 5E) as represented by the earlier plotting. The binary plot of Log-Log (Fig. 5F) by Sahu, ${ }^{19}$ for the interpretation of depositional environment based on grain size values, represents the Upper
Bhuban sandstones to be deposited in the deltaic condition with the association of turbidite sequences. Again, Sahu ${ }^{19}$ established another discriminant function based on graphical parameters of Folk and Ward ${ }^{13}$ to distinguish sediments between aeolian, shallow-agitated marine, beach and fluvio-deltaic conditions. Based on these statistical parameters it is observed that the functions $Y_{1}$ pointed towards beach deposition, $Y_{2}$ represents the environment as shallow agitated marine, $Y_{3}$ also shows shallow agitated marine and $Y_{4}$ showed mostly turbidity current deposition as represented in the Table 4. Therefore, these parameters indicate that the depositional environment was shallow marine during the time of deposition of Upper Bhuban sandstones.

\section{Heavy mineral analysis}

Petrographic microscopy showed the following heavy minerals (Table 5 and Fig. 6):

Zircon: They are mostly euhedral in shape ad few are subhedral and rounded, which represents reworked nature. Long, short and prismatic grains are abundant. Grains are generally colourless in appearance. Broken grains are frequently seen and within some grains the strain effect developed. Most of the grains shows zoning effect. Extinction is parallel.

Tourmaline: They are light brownish to colourless in appearance and pleochroism is commonly seen. Grains are generally subhedral to sub-rounded but rounded grains are also observed. Extinction is parallel.

Rutile: They are generally light to dark red in colour. Dark red grains exhibit nearly opaque character under cross polars. Most of the grains are sub-rounded where extinction is parallel.

Garnet: They can easily be identified because of their high relief and isotropic nature which are euhedral, rounded, sub-rounded or irregular grains with uneven or conchoidal fractures.

Kyanite: They are angular, prismatic, dominantly colourless, weakly pleochroic and exhibit characteristics of cross-fractures.

Sillimanite: They are long, slender, elongated, prismatic and irregular in shapes. The 


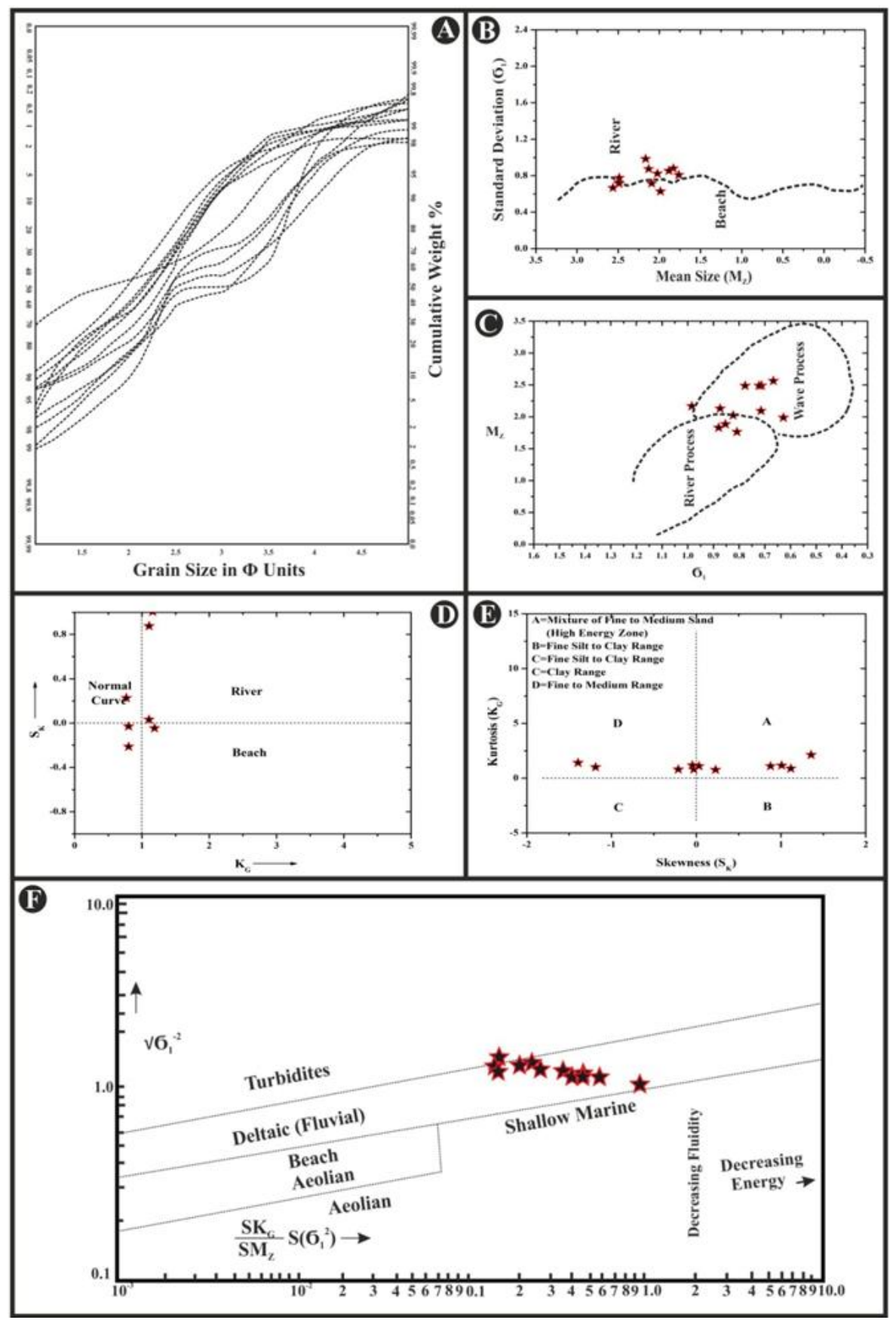

Figure 5 | A. Cumulative grain size curves, B. Binary plot of Graphic Mean $\left(\mathrm{M}_{2}\right)$ vs Standard Deviation $\left(\sigma_{1}\right)^{15}$ representing the depositional conditions, $C$. Binary plot of Mean Size $\left(M_{2}\right)$ vs Standard Deviation $\left(\sigma_{1}\right)^{16}$ suggesting the sediments were deposited by wave processes, D. Skewness $\left(S_{k i}\right)$ vs Kurtosis $\left(K_{G}\right)$ plot ${ }^{17}$ representing the depositional condition of sediments, E. Binary plot of Skewness $\left(\mathrm{S}_{\mathrm{ki}}\right)$ vs Kurtosis $\left(\mathrm{K}_{\mathrm{G}}\right)^{18}$ to depict the energy conditions, F. Log-Log plot $^{19}$ showing the depositional environment. 
fibrous varieties are also identified. They are colourless and extinction is parallel. Cleavage is very distinct.

Epidote: They are greenish yellow in colour and pleochroic in nature. Subrounded to rounded in shape and extinction angle is low.

Chlorite: They are greenish in colour which are dirty in appearance.

Hornblende: They appears green to greenish brown in colour and most of them are sub angular to prismatic. They are prominently pleochroic in nature. Some grains shows overgrowth. Extinction angle varies from $4^{\circ}$ to $24^{\circ}$.

Opaque minerals: Due to lack of distinct optical properties the opaque minerals could not be described properly. However, some are haematite while few are magnetite.

Heavy mineral composition suggests that a significant proportion of the sediments were contributed by acid plutonic rocks. This observation is also supported by the presence of long, slender, prismatic and zoned grains of zircon. In few sections the zircon grains are observed as broken fragments which support the fact that they had undergone a moderate distance of transportation. Characteristics of zircon show that the grains were derived from igneous source. Moreover, the rounded zircons indicate that they must have been contributed by reworked sediments. The occurrence of different derivatives of heavy minerals in the sediments may be attributed to the sources of varied composition. Moreover, the presence of hornblende, kyanite, epidote, sillimanite and garnet suggests metamorphic source rocks. However, the source may lie near to the basin of deposition.

The degree of maturity of sandstones can be measured by the heavy mineral analysis proportion of quartz, feldspar and the rock fragments. It is often expressed in terms of "ZTR Index" proposed by Hubert ${ }^{29}$ The transparent-non micaceous heavy minerals like zircon, tourmaline and rutile are both chemically and mechanically very stable; their combined percentage among other transparent heavy mineral assemblage is defined as ZTR Index. ${ }^{29}$ Recalculated ZTR were plotted in the triangular plot as represented in the Figure 7A. Upper Bhuban sandstones are showing $74.40-82.50 \%$ with the mean ZTR percentage of $77.86 \%$. Zircon individually varies between $27.84-34.93 \%$, tourmaline: $14.77-17.59 \%$ and rutile: $7.39-12.88 \%$.

In the ZTR triangular plot, recalculate percentile values of zircon, tourmaline and rutile are plotted. For the Upper Bhuban Formation the recalculated values vary between $48.94-59.11 \%$ for zircon, tourmaline varies between 27.16 $32.01 \%$ and rutile varies between $13.72-21.99 \%$. In the ZTR triangular plot (Fig. 7A) most of the Upper Bhuban sandstones are clustered within the $A_{1}$ tier of $A$ block. This represents the proportion of zircon is the highest followed by tourmaline and rutile. The range of ZTR maturity index for Upper Bhuban sandstone varies between 74.40 to $82.50 \%$. So, it can be inferred that the sediments, forming the rocks, are submature in nature.

\section{Discussion}

Petrographic quantitative modal analysis data are commonly used to classify the sandstones. ${ }^{30,31}$ Modal analysis of Upper Bhuban sandstones are showing the dominance of quartz (68.31-86.55\%) which is followed by rock fragments (6.48-22.06\%) and feldspars (5.15$12.23 \%)$. The recalculated percentile values of quartz, feldspars and rock fragments are plotted in the ternary plot of QFLafter Pettijohn ${ }^{30}$ and ternary plot of QFRafter Folk. ${ }^{31}$ Plotting in the ternary plot of QFL indicated that most of the Upper Bhuban samples are clustered in the field of sublith arenite and few are in plotted in the field of lithic wacke as represented in the Figure 8A. Similarly, in the QFR ternary plot after Folk, ${ }^{1}$ the samples are clustered in the field of sublith arenite which is represented in the Figure 8B. Thus, Upper Bhuban sandstones are of sublith arenite and lithic wacke type.

Collision between Indian and Eurasian plate took place during Paleocene-Eocene, nearly 55$51 \mathrm{Ma}^{33-37}$ The Brahmaputra river was following the marginal zones of India-Eurasian plate and continuously draining the N-S trending JurassicPaleogene Trans Himalayan arc, N-S suture zones, Tethyan Himalayan zone and Precam- 


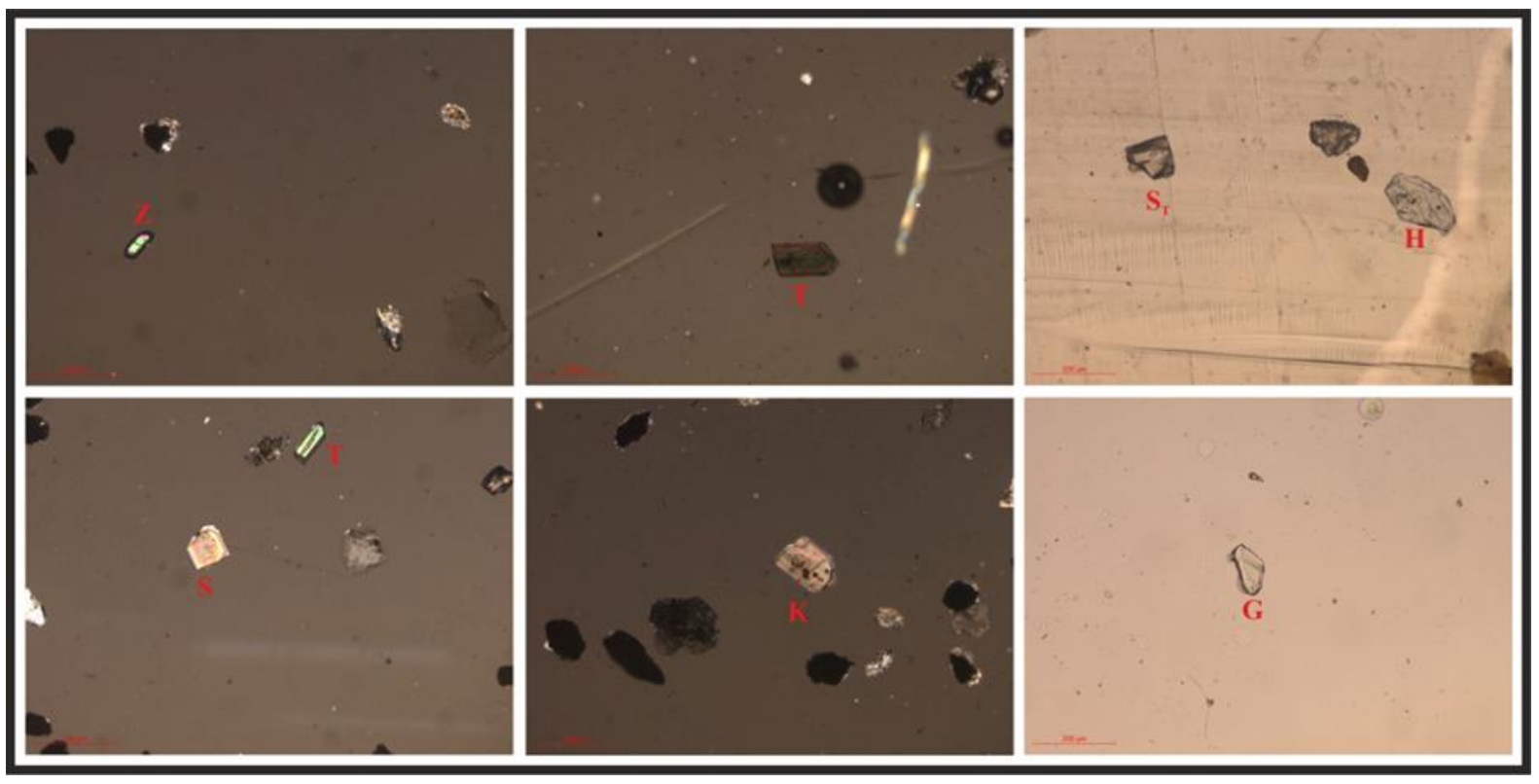

Figure 6 | Heavy minerals observed under microscope (where, Z: zircon, T: tourmaline, $\mathrm{S}_{\mathrm{T}}$ : staurolite, H: hypersthenes, R: rutile, S: sillimanite, K: kyanite \& G: garnet).

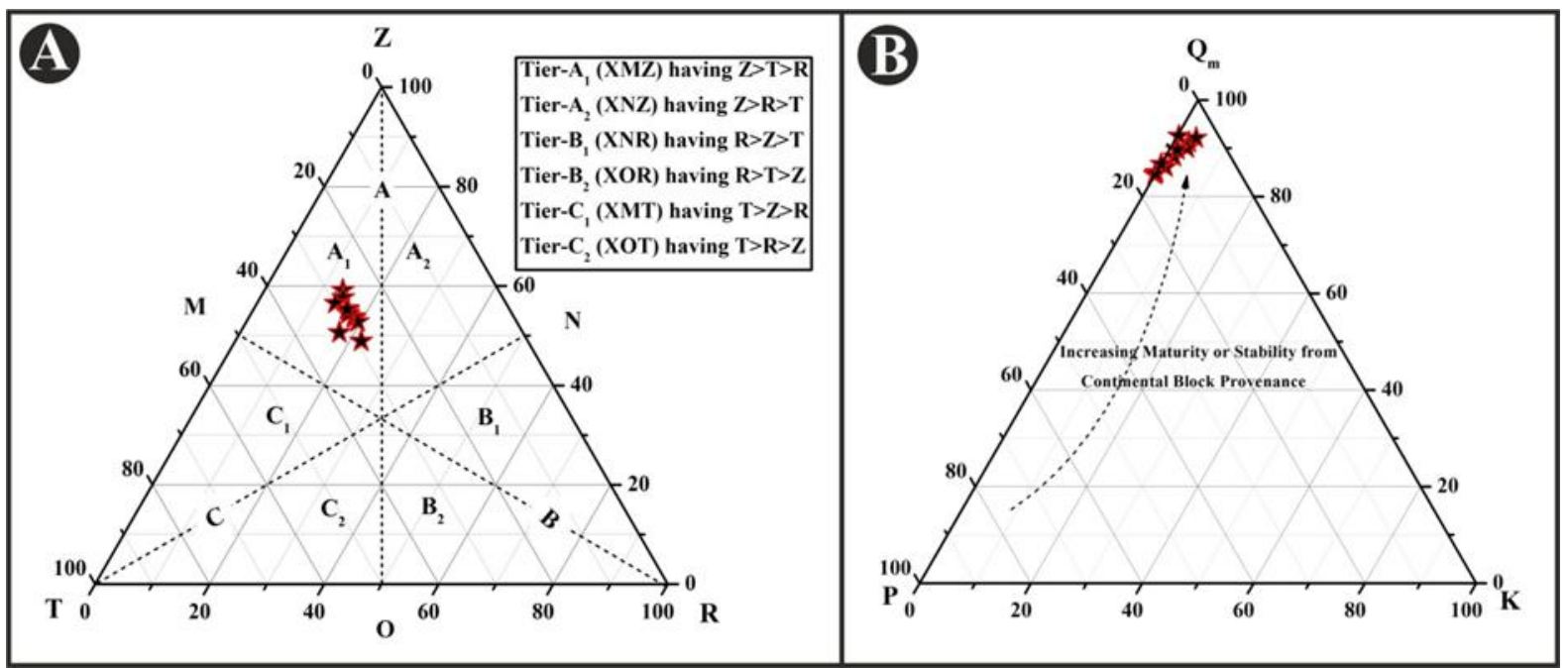

Figure 7 | A. ZTR index ${ }^{29}$ of Upper Bhuban sandstones. B. $Q_{m} P K$ ternary plot ${ }^{44}$ representing continental derivation of sediments with increasing maturity index. 


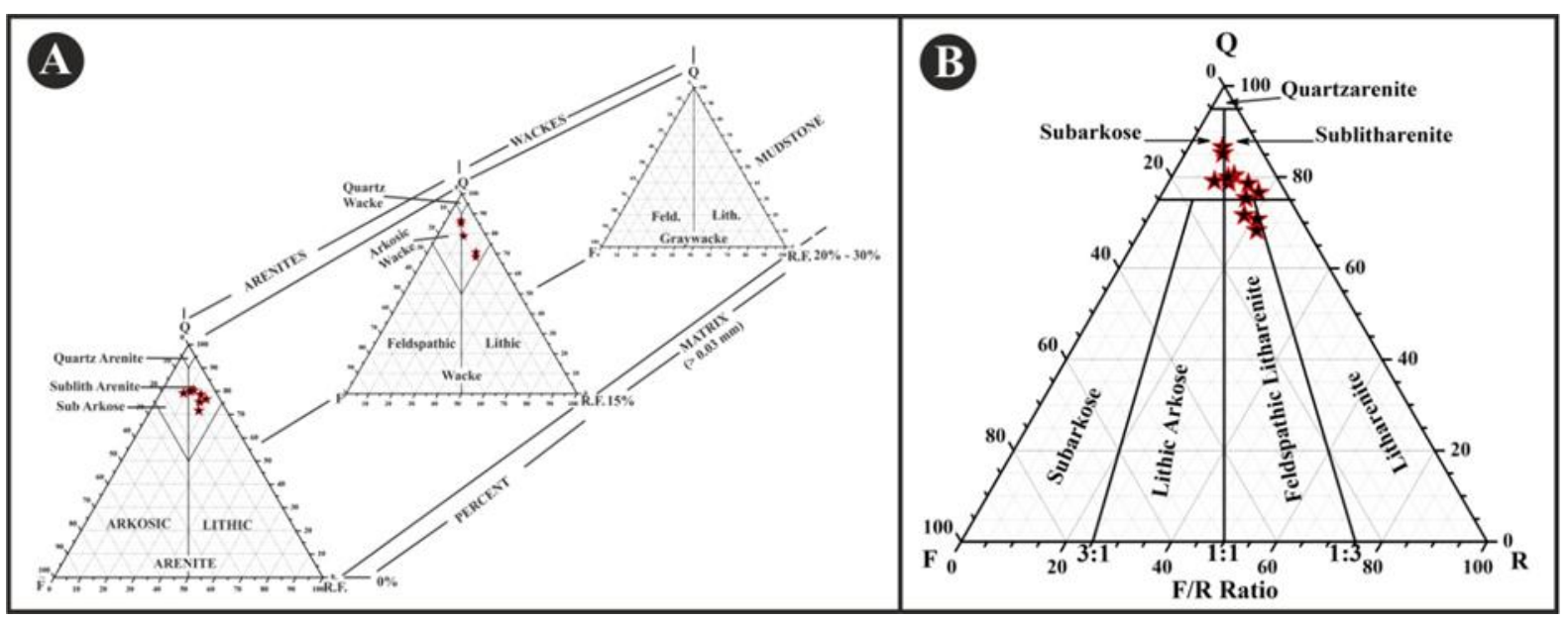

Figure 8 | Petrographic classification of sandstones. A. QFL. ${ }^{30}$ B. QFR. ${ }^{31}$

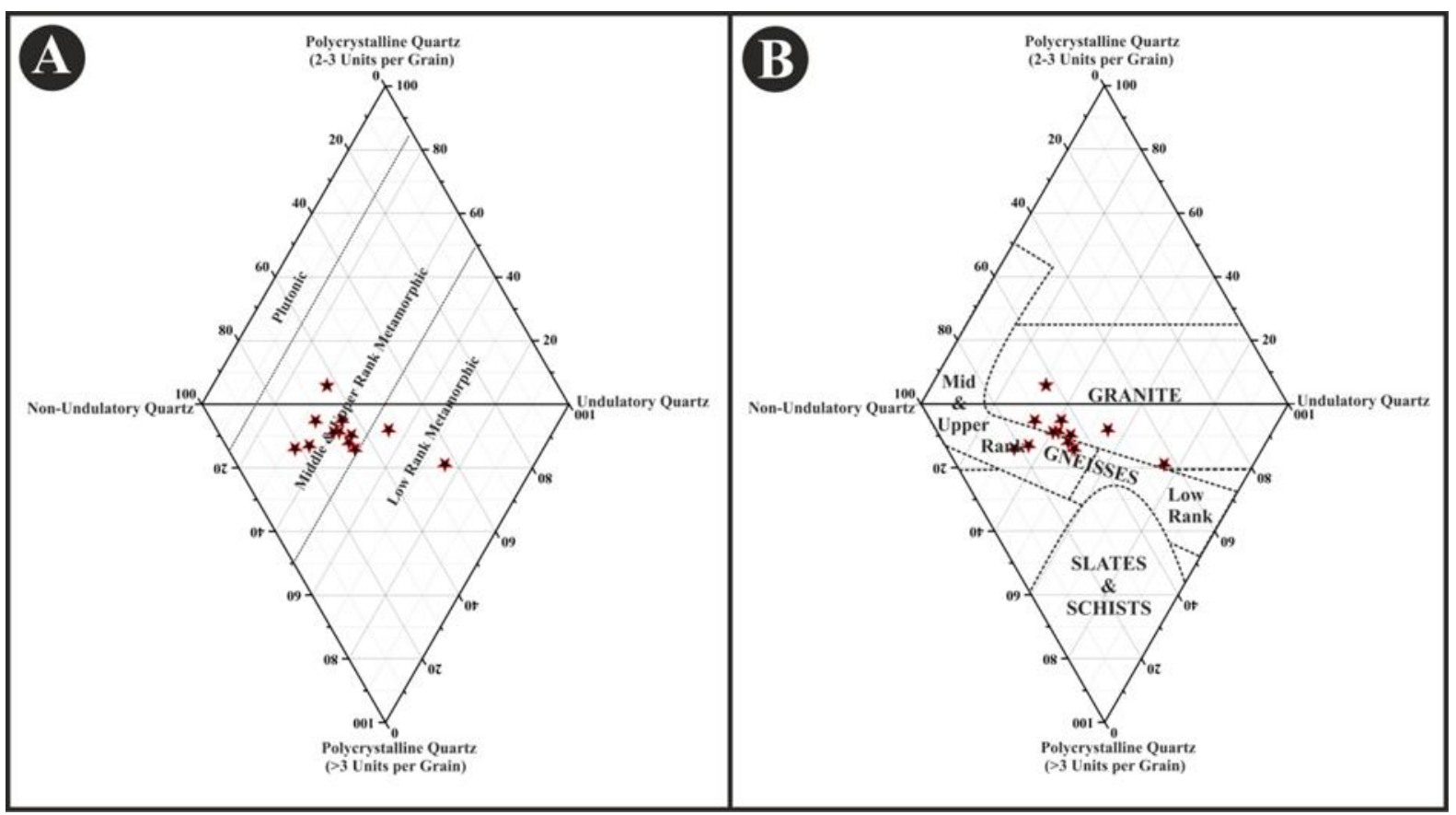

Figure 9 | Monocrystalline and polycrystalline quartz are plotted in - A. Diamond Diagram ${ }^{7}$ representing the derivation of sediments from upper to middle rank metamorphic rocks; B. Diamond Plot $^{8}$ representing derivation of sediments from granite and gneisses. 


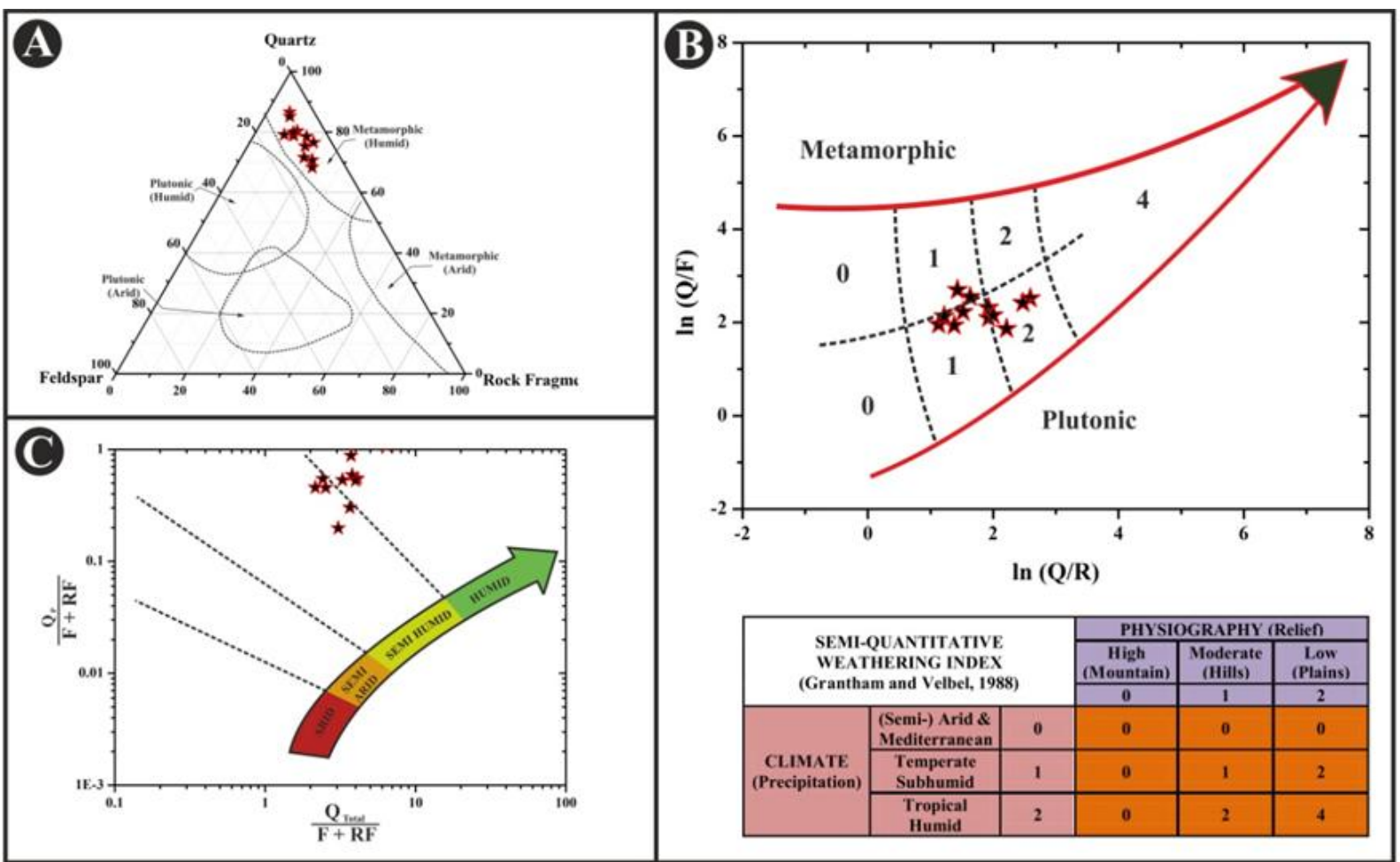

Figure 10 | Paleo-climatic conditions of Upper Bhuban Formation - A. Ternary QFR plot ${ }^{45}$ representing humid climatic condition. B. Semi Quantitative Weathering Index ${ }^{11}$ and binary plot of $\ln (Q / R)$ vs $\ln (Q / F)^{46}$ representing moderate nature of weathering. $\mathbf{C}$. Bivariate plot $^{12}$ of modal data representing humid to semi humid climatic conditions.

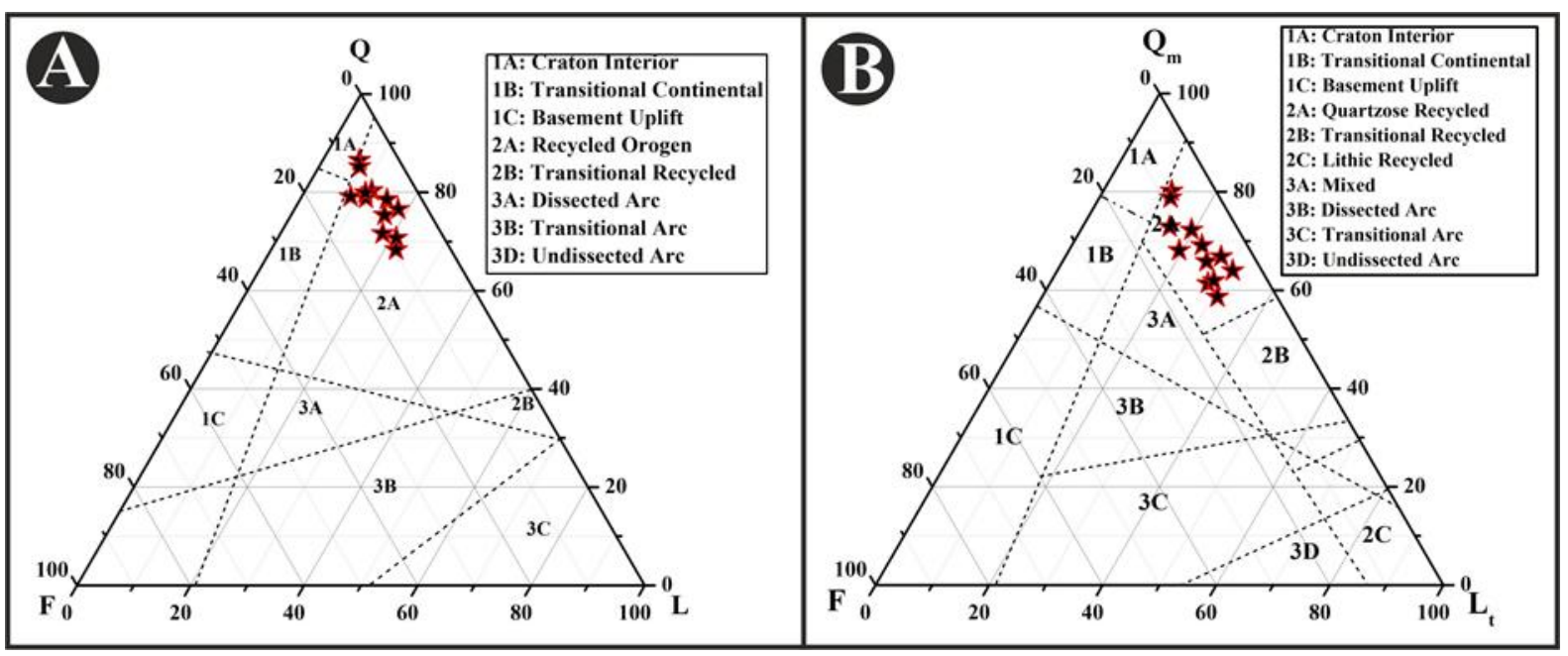

Figure 11 | Petrographic tectonic setting discriminant plot - A. QFL ternary plot. ${ }^{9}$ B. $Q_{m} F L_{t}$ ternary plot ${ }^{10}$ representing recycled orogen and quartzose recycled orogen. 
brian-Paleozoic Indian crustsince its origin..$^{3840}$ The litho-association of these sub-divisions comprises of high-medium grade metamorphic and plutonic rocks including gneisses and granites, schist, amphibolites, quartzite and ophiolitic complexes. It is considered that the sediments were primarily derived from the Himalayan ranges for the Surma basin. The paleoBrahmaputra and its tributaries played significant role for shedding the uprising Himalaya ranges and deposited into Surma basin. ${ }^{40}$

It is also considered that the near most subduction and ophiolitic complexes of Naga hills (Naga Hill Ophiolites) contributed sediments to the Surma basin. During Late Jurassic to Eocene the litho association of Naga hill ophiolitic complexes comprises of felsic intrusive, maficultramafic rocks and pelagic oceanic sediments from where the sediments were sourced to Surma basin.

Brahmaputra river has the highest sediment flux continuously eroding its catchment areas and transported sediments towards the southeastern basinal part which covers the Upper Assam and Bengal basin. ${ }^{41,42}$ Najman et al ${ }^{40}$ reported that Brahmaputra river was initially following a straight way towards the Bengal basin including its northeastern extension i.e. Surma basin (present study area). Surma basin continuously received the sediments till the end of Miocene. ${ }^{40,43}$ But due to evolution of Shillong plateau and development of Naga hill ranges and its adjoining parts as a result of collision that diverted the flow of Brahmaputra river towards the western part of the Assam; by the end of Miocene Shillong plateau attained an adequate height to divert the Brahmaputra river. ${ }^{43}$ Due to development of these tectonic domains the sediment supply to Surma basin from the Himalayan ranges along with the neighboring orogens seized.

Provenance of the clastic sediment is considered as a very significant part of a basin analysis which is often determined from the nature and varieties of framework grains. Quantitative data of monocrystalline (both undulatory and nonundulatory) and polycrystalline (2-3 grains and $>3$ grains per quartz) varieties of quartz are com- monly used to infer the nature of source rocks. Petrographical modal data are showing the dominance of $\mathrm{QM}_{\mathrm{NU}}(22.84 \%)$ which is followed by $\mathrm{QM}_{\mathrm{U}}(13.62 \%), \mathrm{QP}_{>3}(4.23 \%)$ and $\mathrm{QP}_{2-3}(2.59 \%)$. Basu et al. ${ }^{7}$ proposed the diamond diagram based on modal data to decipher the provenance. While plotting in the diamond diagram (Fig. 9A) the Upper Bhuban sandstones are clustered in the middle and upper rank metamorphic rocks. This observation signifies the contribution of sediments from metamorphic terrains. Tortosa et al. ${ }^{8}$ proposed another provenance plot by keeping the same parameters of diamond diagram with the introduction of new fields of source rocks. In this plot (Fig. 9B) most of the samples are occupying the center position which indicates less abundance of polycrystalline quartz with more non-undulatory monocrystalline quartz. Therefore, it can be inferred that the sediments were mostly sourced from the granitic terrain. Based on these discrimination plottings, it can be inferred that the sediments were sourced from felsic nature, possibly from middle to upper rank metamorphics and granitoids.

Dickinson et al. ${ }^{10}$ proposed the ternary plot of $\mathrm{Q}_{\mathrm{m}} \mathrm{PK}$ in order to represent the derivation of sediments and also the extent of maturity developed during transportation. The analyzed sandstone samples are showing (Fig. 7B) a mature nature with the increasing concentration of quartz due to moderate to long distance transport. It indicates the derivation of the sediments due to weathering from continental block provenance. Moreover based on modal count of petrographic data showing less enrichment of feldspars $\left(\mathrm{P}_{\mathrm{C}, \mathrm{Na}}: 4.12 \%\right.$ and $\left.\mathrm{F}_{\mathrm{K}}: 0.59 \%\right)$ which is possibly due to moderate to long distance transportation or reworking of the sediments.

Based on the heavy mineral assemblages it can be interpreted that the sediments of Upper Bhuban Formation were derived from varied sources. Both igneous and metamorphic source rocks have contributed the major portion of the sediments. But the presence of rounded and subrounded grains (mostly zircon) suggested some contribution due to reworking of sediments. The broken zircon grains and sub 
rounded outlines of various grains suggest a moderate distance of transportation of the sediments. It can be considered that the sediments for Upper Bhuban sandstones of the study area were primarily supplied from the uplifted and eroded Himalayan crystalline felsic terrain, but contribution from the nearest orogen like Shillong plateau, Naga hill ranges and Indo-Burmese Arc are also considerable.

Modal count of petrographic data provides important clues to infer the climatic condition prevailing at the time of deposition of sediments in a basin. Suttner and Basu ${ }^{45}$ suggested that the high abundance of quartz, comparatively less amount of feldspar and rock fragments (Q-F-R: 77.60-8.45-13.95) indicates the derivation of sediments from metamorphic source area under humid climatic condition which is represented in the bivariate plot of QFR (Fig. 10A). Grantham and Velbel ${ }^{11}$ proposed the weathering index: WI=CxR (WI-Weathering index, C-Climate and R -Relief) in combination with the bivariate plot of $\ln (\mathrm{Q} / \mathrm{R})$ vs $\ln (\mathrm{Q} / \mathrm{F})$ after Weltje ${ }^{46}$ (Fig. 10B) can well represents the nature of paleoclimatic conditions. In that plot Upper Bhuban sandstones are showing a mixed nature of metamorphic and plutonic source rocks with the weathering indices between 1-2 suggesting a moderate nature of weathering under humid to sub-humid climatic conditions. Similar interpretation is also observed from the bivariate plot of ratios of $\left(\mathrm{Q}_{\mathrm{Tota}} \mathrm{V}\right.$ $\mathrm{F}+\mathrm{RF})$ vs $\left(\mathrm{Q}_{\mathrm{p}} / \mathrm{F}+\mathrm{RF}\right)$ after Suttner and Dutta $^{12}$ where samples are clustered between semihumid to humid climatic conditions (Fig. 10C).

In order to determine the tectonic settings of the study area, petrographic modal data are plotted in the ternary plot of QFL after Dickinson \& Suczeck ${ }^{9}$ (Fig. 11A) and ternary plot of $\mathrm{Q}_{\mathrm{m}} \mathrm{FL}_{\mathrm{t}}$ after Dickinson et al. ${ }^{10}$ (Fig. 11B). The plots representing a recycled orogen and quartzose recycled setting respectively. Moreover, based on the tectonic setup of the study area suggesting that it is located near convergent plate margin between Indian and Burmese plate. Therefore, the present study area of Surma Basin can be said as falling in recycled orogen to active continental margin.

\section{Conclusion}

The analyzed sandstone samples of Upper Bhuban Formation exposed in Aizawl are mainly litharenite and wacke type. Granulometric analyses suggest a shallow marine environment under the influence of fluvio-deltaic conditions. Sediments were primarily supplied from the granitoids and their metamorphic equivalents derived from Himalayan ranges which were transported by paleo-Brahmaputra and its tributaries forming a deltaic condition in the study area. The alternate event of transgression and regression of sea causes the deposition of the sediments under shallow marine to deltaic conditions. Some amount of sediments was also sourced from the near most orogens including Shillong plateau, Naga hills and Indo Burmese ranges. The source sediments have undergone a mild to moderate nature of weathering within a semi-humid to humid climatic conditions before the deposition took place in Surma basin. The sediments were moderately matured.

Although it is difficult to infer the tectonic settings solely based on the petrographic analysis, but in support of regional tectonic configuration, the Surma basin has an active continental margin to recycled orogen setting.

\section{References}

I. Ganju, J. L. (1975). Geology of Mizoram. Geology Mineral ES Metallurgical Society of India 48, 17-26.

2. Nandy, D.R., Dasgupta, S., Sarkar, K. \& Ganguly, A. (1983). Tectonic evolution of Tripura-Mizoram Fold Belt, Surma Basin, northeast India. Quarterly Journal, Geology Mineral ES Metallurgical Society of India 55-4, I86-I94.

3. Dasgupta, S. (1984). Tectonic trends in Surma Basin and possible genesis of the folded belt. Records Geological Survey of India II3-IV, 58-6I.

4. Alam, M., Alam, M. M., Curray, J. R., Chowdhury, M. L. R. and Gani, M. R. (2003). An overview of the sedimentary geology of the Bengal Basin in relation to the regional tectonic framework and basin-fill history. Sedimentary Geology I55, 179-208. 
5. Uddin, A. \& Lundberg, N. (1999). A paleoBrahmaputra? Subsurface lithofacies analysis of Miocene deltaic sediments in the Himalayan-Bengal system, Bangladesh. Sedimentary Geology 123, 239-254.

6. Tiwari, R.P. \& Kachhara, R.P. (2003). Molluscan biostratigraphy of the tertiary sediments of Mizoram, India. Journal of Paleontological Society of India 48, 59-82.

7. Basu, A., Young, S., Suttner, L., James, W. \& Mack, G. (1975). Re-evaluation of the use of undulatory extinction and crystallinity in detrital quartz for provenance interpretation. Journal of Sedimentary Petrology 45, 873882.

8. Tortosa, A., Palomares, M. \& Arribas, J. (I99I). Quartz grain types in Holocene deposits from the Spanish Central System: some problems in provenance analysis. Geological Society, London, Special Publication 57, 47-54.

9. Dickinson, W.R. \& Suczek, C.A. (1979). Plate tectonics and sandstone compositions. American Association of Petroleum Geologist Bulletin 63, 2164-2182.

Io. Dickinson, W.R., Beard, L., Brakenridge, G.R., Erjavec, J.L., Ferguson, R.C., Inman, K.F., Knepp, R.E.X.A., Lindberg, F. \& Ryberg, P.T. (1983). Provenance of North American Phanerozoic sandstones in relation to tectonic setting. Bulletin, Geological Society of America $94,222-235$.

II. Grantham, J. H. \& Velbel, M. A. (1988). The influence of climate and topography on rock-fragment abundance in modern fluvial sands of the southern Blue Ridges mountains, North Carolina. Journal of Sedimentary Petrology 58, 219-227.

I2. Suttner, L. J. \& Dutta, P. K. (1986). Alluvial sandstone composition and paleoclimate, i, framework mineralogy. Journal of Sedimentary Petrology 56, 329-345.

I3. Folk, R.L. \& Ward, W. C. (1975). Brazos River Bar: A study in the significance of grain size parameters. Journal of Sedimentary Petrology 27-I, 3-26.

14. Cadigan, R. A. (196I). Geologic Interpretation of grainsize distribution measurement of Colorado Plateau sedimentary rocks. Journal of Geology 69, I2I-I42.

15. Friedman, G. M. (1967). Dynamic processes and statistical parameters compared for size frequency distribution of beach and river sands. Journal of Sedimentary Petrology 37-2, 327-354.

16. Goldberry, R. (1980). Use of grain size frequency data to interpret the depositional environment of the Pliocene
Pleshet Formation, Beer Sheva, Israel. Journal of Sedimentary Petrology 50-3, 843-856.

17. Friedman, G. M. (196I). Distinction between dune, beach, and river sands from their textural characteristics. Journal of Sedimentary Petrology 3I-4, 5I4-529.

18. Thompson, A. W. (1972). Calculation of true volume grain diameter. Metallography 5, 366-369.

19. Sahu, B. K. (1964). Depositional mechanism from the size analysis of clastic sediments. Journal of Sedimentary Petrology 34-I, 73-83.

20. Banerjee, S. P., Sarkar, K. \& Dasgupta, S. (1979). Geological mapping in parts of Serchip-Thenzuwal area and Mineral Survey, Aizwal dist., Mizoram. Unpublished Progress Report, Geological Survey of India: 1976-77.

2I. Bhaduri, A. (20II). State Geological and Mineral MapsGeological Survey of India Miscellaneous Publication Series. www.indiawaterportal.org/articles/state-geologyand-mineral-maps-geological-survey-india-miscellaneouspublication-series (24 ${ }^{\text {th }}$ Sept. 20II)

22. Tiwari, R. P., Rajkonwar, C., Lalchawimawii, Lalnuntluanga, P., Malsawma, J., Ralte, V. Z. \& Patel, S. J. (20II). Trace fossil from Bhuban Formation, Surma Group (Lower to Middle Miocene) of Mizoram India and their palaeoenvironmental significance. Journal of Earth System Science I2O-6, II27-II43.

23. Rajkonwar, C., Tiwari, R. P. \& Patel, S. J. (2013). Arenicolites helixus isp. nov. and associated ichnofossils from the Bhuban Formation, Surma Group (Lower-Middle Miocene) of Aizawl, Mizoram, India. Himalayan Geology 34-I, I8-37.

24. Tiwari, R. P., Malsawma, J., Sangode, S. J. \& Arora, B. R. (2007). Magnetostratigraphy of a part of Upper Bhuban sequence (Surma Group), Aizawl, Mizoram. Journal Geological Society of India 70-4, 667-674.

25. Malsawma, J., Lalnuntluanga, P., Badekar, A., Sangode, S. J. \& Tiwari, R. P. (2010). Magnetic polarity stratigraphy of the Bhuban Succession, Surma Group, TripuraMizoram accretionary belt. Journal Geological Society of India 76, II9-I33.

26. Gazzi, P. (1966). Le arenarie del flysch sopracretaceo dell' Appennino modenese; correlazioni con il flysch di Monghidoro. Mineralogica e Petrografica Acta I2, 6997 .

27. Dickinson, W.R. (1970). Interpreting detrital modes of greywackes and arkose. Journal of Sedimentary Petrology 
40, 695-707.

28. Ingersoll, R. V., Bullard, T. F., Ford, R. L., Grimm, J. P., Pickle, J. D. \& Sares, S. W. (1984). The effect of grain size on detrital modes: A test of the Gazzi-Dickinsom point counting method. Journal of Sedimentary Petrology 54-I, IO3-II6.

29. Hubert, J. F. (1962). A zircon-tourmaline-rutile maturity index and the interdependence of the composition of heavy mineral assemblages with the gross composition and texture of sandstones. Journal of Sedimentary Petrology 33-3, 440-450.

3o. Pettijohn, F.J., Potter, P.E. \& Siever, R. (1972). Sand and Sandstones. New York, Springer-Verlag.

31. Folk, R.L. (1974). Petrology of Sedimentary Rocks. Hemphill Publishing Company.

32. Critelli, S. \& Garzanti, E. (1994). Provenance of the lower Tertiary Murree redbeds (Hazara-Kashmir syntaxis, Pakistan) and initial rising of the Himalayas. Sedimentary Geology 89, 265-284.

33. Rowley, D. B. (1996). Age of initiation of collision between India and Asia: a review of stratigraphic data. Earth and Planetary Science Letters I45, I-I3.

34. Pivnik, D. A. \& Wells, N. A. (1996). The transition from Tethys to the Himalaya as recorded in northwest Pakistan. Geological Society of America Bulletin 108, 1295 -I3I3.

35. Guillot, S., Garzanti, E., Baratoux, D., Marquer, D., Mahe'o, G. \& Sigoyer, J. De. (2003). Reconstructing the total shortening history of the NW Himalaya. Geochemistry Geophysics Geosystems 4, DOI: Io.IO29/2002GCoOO484.

36. DeCelles, P.G., Gehrels, G. E., Najman, Y., Martina, A. J., Carter, A. \& Garzanti, E. (2004). Detrital geochronology and geochemistry of Cretaceous-Early Miocene strata of Nepal: implications for timing and diachroneity of initial Himalayan orogenesis. Earth and Planetary Science Letters 227, 313-330.

37. Hodges, K.V. (2000). Tectonics of the Himalaya and southern Tibet from two perspectives. Geological Society of America, Bulletin II2, 324-350.

38. Liang, Y-H. (2008). Detrital zircon evidence from Burma for reorganization of the Eastern Himalayan river system. American Journal of Science 308, 618-638.

39. Chiu, H-Y. (2009). Zircon $\mathrm{U}-\mathrm{Pb}$ and $\mathrm{Hf}$ isotopic con- straints from eastern Transhimalayan batholiths on the precollisional magmatic and tectonic evolution in southern Tibet. Tectonophysics 477, 3-19.

40. Najmana, Y., Braccialia, L., Parrish, R. R., Chistyc, E. \& Copley, A. (2016). Evolving strain partitioning in the Eastern Himalaya: The growth of the Shillong Plateau. Earth and Planetary Science Letters 433, I-9.

4I. Summerfield, M. A. \& Hulton, N. J. (1994). Natural controls of fluvial denudation rates in major world drainage basins. Journal of Geophysical Research 99, I387I-I3883.

42. Stewart, R. J., Hallet, B., Zeitler, P. K., Malloy, M. A., Allen, C. M. \& Trippett, D. (2008). Brahmaputra sediment flux dominated by highly localized rapid erosion from the easternmost Himalaya. The Geological Society of America 36-9, 7II-7I4.

43. Clark, M. K. \& Bilham, R. (2008). Miocene rise of the Shillong Plateau and the beginning of the end for the Eastern Himalaya. Earth and Planetary Science Letters 269, 337-35I.

44. Dickinson, W.R. (1985). Interpreting provenance relations from detrital modes of sandstones. In: G. G. Zuffa (ed.), Provenance of Arenites, pp. 333-36I.

45. Suttner, L. J. \& Basu, A. (198I). Climate and the origin of quartz arenites. Journal of Sedimentary Petrology 54, I235-I246.

46. Weltje, G. J. (1994). Provenance and Dispersal of Sandsized Sediments: Reconstruction of Dispersal Patters and Sources of Sand-sized Sediments by Means of Inverse Modelling Techniques. PhD dissertation, Utrecht University, Geologica Ultraiectina.

47. Baily, S. W., Bell, R. A. \& Peng, C. J. (1958). Plastic deformation of quartz in nature. Geological Society of America, Bulletin 69, I443-1466.

48. Blatt, H., Middleton, G. \& Murray, R. (1980). Origin of Sedimentary Rocks. Prentice-Hall, New Jersey.

49. Conolly, J. R. (1965). The occurrence of polycrystallinity and undulatory extinction in quartz in sandstones. Journal of Sedimentary Petrology 35, II6-I35.

50. Curray, J. R. (1991). Geological history of the Bengal geosyncline. Journal of Association Exploration Geophysics XII, 209-219.

5I. Ingersoll, R. N., Graham, S. A. \& Dickinson, W. R. (1995). Remnant ocean basin. In: Busby, C. J. \& Inger- 
soll, R. V. (Eds.), Tectonics of Sedimentary Basin. Blackwell, Oxford, 363-39I.

52. Johnson, S.Y. \& Alam, A. M. N. (199I). Sedimentation and tectonics of the Sylhet trough, Bangladesh. Geological Society of America, Bulletin I03, I513-I527.

53. Mitchell, A. H. G. \& Reading, H. G. (1986). Sedimentation and tectonics. In: Sedimentary Environments and Facies (Reading, H. G., ed.), Blackwell Scientific Publications, 47I-519.

54. Najman, Y. \& Garzanti, E. (2000). Reconstructing early Himalayan tectonic evolution and paleogeography from Tertiary foreland basin sedimentary rocks, northern India. Geological Society of America, Bulletin II2, 435449 .

55. Nandy, D.R., Mukherjee, R.N. \& Majumdar, T. (1972). Geological mapping and mineral survey in parts of Mizoram. Geological Survey of India, Progress Report for F.S. 1971-72 (unpublished).
56. Nandy, D.R. \& Sarkar, K. (1973). Geological mapping and mineral survey in parts of Aizawl District, Mizoram. Geological Survey of India. Progress Report for F.S.Ig7I72 (unpublished).

57. Pettijohn, F. J. (1975). Sedimentary Rocks, $3^{\text {rd }}$ Ed. Harper and Row, New York.

58. Phukan, P.P. \& Bogohain, P. (2014). Depositional environment and provenance of the Surma Group of rock exposed along Bawngkawn-Durtlang road section, Aizawl, Mizoram. In: Unpublished M.Sc. Dissertation.

59. Reineck, H. E. \& Singh, I. R. (1973). Depositional Sedimentary Environments. Springer Verlag, Berlin Heildelberg. New York.

6o. Uddin, A. \& Lundberg, N. (1998). Cenozoic history of the Himalayan-Bengal system: sand composition in the Bengal basin, Bangladesh. Geological Society of America Bulletin IIO, 497-5II. 